\title{
PERENCANAAN DAN PERANCANGAN KAMPUNG WISATA WATU GONG KELURAHAN TLOGOMAS RW 03 KECAMATAN LOWOKWARU KOTA MALANG
}

\author{
Rifky Aldila Primasworo, ST., MT \\ Program Studi Teknik Sipil, Fakultas Teknik \\ Universitas Tribhuwana Tunggadewi Malang \\ Email : rifky.unitrimalang@gmail.com
}

\begin{abstract}
Abstrak
Kota Malang memiliki segudang aset dan potensi untuk bisa mewujudkan perancangan kota secara ideal, memberi nilai tambah fisik dan non-fisik. Salah satunya Kelurahan yang berada Di Kota Malang yaitru Kelurahan Tlogomas. Kelurahan ini yang memiliki peninggalan sejarah pada jaman Kerajaan Kanjuruhan. Beberapa situs dan peninggalan kerajaan pada masa itu yang tersebar berada Di Kelurahan Tlogomas Di RW 03 Kota Malang. Beberapa potensi fisik dan non-fisik di Kampung Watu Gong Tlogomas terutama Di RW 03 antara lain potensi jalan yang mudah, sumber air dan daerah aliran sungai, terdapat Situs Peninggalan Kerajaan Kanjuruhan, produksi Kerajinan masyarakat lokal seperti kompor dan pengolahan limbah plastik, tersedianya gapura yang memiliki unsur sejarah dan terselenggaranya beberapa eveneven kesenian tradisional. Gambaran objek atau ide rancangan dari perencanaan yang berada Di Kelurahan Tlogomas RW 03 Kecamatan Lowokwaru Kota Malang terdiri dari 6 (enam) bagian meliputi 1.Pintu gerbang utama ; 2.Sepanjang jalan Kanjuruhan (utara); 3.Sepanjang jalan Kanjuruhan (Timur-barat) ; 4.Pintu gerbang selatan; 5.Gang IV (kawasan menuju situs); 6.Pendopo Agung.

Strategi yang dilakukan dalam mengenbangkan kampug wisata Watu Gong adalah pengaplikasian 5 unsur (unsur edukatif, ekologis, budaya, estetika dan unsur ekonomi) ke dalam masing-masing zonasi perencanaan ruang (Zona inti, zona pengembangan/buffer area dan zona konservasi).
\end{abstract}

Kata-kata kunci : Tlogomas, Watu Gong, Perencanaan

\begin{abstract}
Malang city has a myriad of assets thats potential to be realized in urban design ideally, given the added value of physical and non-physical. One of the district area in Malang is Tlogomas district. These district have historical relics on Kanjuruhan Kingdom era. Some of sites dan relics are spread in RW 03 malang Tlogomas District at that time. Some of the potential physical and non-physical in Watu Gong Tlogomas in RW 03, such as potential easy road, water resources and watersheds, there is a World Heritage kingdom Kanjuruhan, production Craft local communities such as stoves and processing of plastic waste, available
\end{abstract}


arch has elements of history and implementation some of the traditional art events. Description of design planning idea in Tlogomas district RW 03 Malang consist of 6 (six) section (1) main gate; (2) along of Kanjuruhan road/north (3) along of Kanjuruhan road (north-west) (4) South gate; (5) fourth street; (6) Pendopo court

The strategies in developing the tourist district of Watu Gong is the application of the five elements (elements of educational, ecological, cultural, aesthetic and economic elements) into each zone of space planning (Core Zone, the development zone / buffer areas and conservation zones).

Keywords : Tlogomas, Watugong, Planning

\section{Pendahuluan}

Kota adalah pusat kehidupan yang dapat dilihat dari berbagai macam sudut pandang pendekatan. Aspek tersebut memberikan gambaran bahwa kota menjadi tempat manusia atau masyarakat berperilaku mengisi aktifitas kehidupannya sehari-hari Sedangkan Penataan ruang adalah suatu sistem proses perencanaan tata ruang, pemanfaatan ruang, dan pengendalian pemanfaatan ruang

Kota Malang memiliki segudang aset dan potensi untuk bisa mewujudkan perancangan kota secara ideal, memberi nilai tambah fisik dan non-fisik. Salah satu event Kota Malang melalui Badan Perencanaan Pembangunan Daerah yaitu menyelenggarakan Festival Rancang Malang. Kegiatan ini merupakan sebuah kegiatan kompetisi perancangan yang dilakukan secara partisipatif oleh masyarakat, dibantu tim pendamping (dapat diusulkan mandiri oleh masyarakat dan atau dibantu perguruan tinggi) untuk mendorong lahirnya kampung tematik khas Kota Malang.
Salah satunya Kelurahan yang berada Di Kota Malang yaitru Kelurahan Tlogomas. Kelurahan Tlogomas merupakan Kelurahan yang memiliki peninggalan sejarah pada jaman Kerajaan Kanjuruhan. Bangsa yang besar terlahir karena memiliki sejarah, kebudayaan dan peradaban yang kuat.Kebudayaan dan peradaban itu ditandai dengan peninggalan atau situs situs. Sejarah kota Malang tidak terlepas dari sejarah kerajaan Kanjuruhan. Ada banyak situs dan peninggalan kerajaan pada masa itu yang tersebar di seluruh penjuru kota dan kabupaten Malang yang sampai sekarang masih ada dan dilestarikan.Tidak terkecuali situs yang ada di kelurahan Tlogomas. Di RW. 03 Tlogomas

Situs peninggalan kerajaan Kanjuruhan pada abad ke 7 yang berupa Batu yang menyerupai atau berbentuk seperti Gong. Konon batu peninggalan tersebut merupakan ompak atau pondasi dari tiang/penyangga sebuah bangunan suci tempat para Brahmana untuk bersemedi, menuntut ilmu, dan melatih olah kanuragan. 
Oleh karena perlu adanya tetap menjaga dan melestarikan peninggalan tersebut, Perlu adanya merancang dan menata kawasan tersebut menjadi sebuah kawasan yang mencerminkan ciri khas sebuah kampung tematik, unik klasik dan menarik yaitu "Kampung Situs Watu Gong".

\section{SUMBER InSPIRASI}

a) Sejarah Awal Perkembangan

Kampung Watu Gong Kecamatan Lowokwaru Kota Malang

Dukuh/ lingkungan Watu Gong merupakan sebuah wilayah yang berada Di Kelurahan Tlogomas Kecamatan Lowokwaru Kota Malang sejak tahun 19897 menurut PP No.15. sebelum tahun 1987 wilayah ini masuk wilayah Kabupaten Malang Di bawah Kecamatan Dau. Pada masa Belanda daerah ini masuk dalam district Dau Afdeling Malang sesuai dengan staatblad No. 16 Tahun 1819.

Perkembangan nama "Tlogomas" merupakan nama baru. Karena dalam peta yang dibuat oleh Bosch tahun 1923 berkenaan dengan daerah DinoyoMerjosari. Nama Tlogomas belum ada. Yang ada adalah Ngelo, Karuman, Gayungan, Pelandungan/Kelandungan (nama-nama ini sekarang merupakan wilayah lingkungan Di Kelurahan Tlogomas), Merjoyo, Merjosari, Dinoyo, dan Ketawanggede. Diduga nama Tlogomas terbentuk sekitar tahun 30-an, ketika masyarakat sering menemukan benda-benda dari emas di dekat sumber air (telaga), sehingga daerah temuan tersebut dikenal dengan nama "Telogo mas"

Mengenai Dukuh Watu Gong yang berada Di Wilayah RW 03 Kelurahan Tlogomas. Dukuh tersebut dinamakan "Watugong" sebab di tempat tersebut terdapat tinggalan berupa batu-batu besar mirip alat musik tradisonal yaitu "Gong". Situs Watugong yang bangunan pengamannya diresmikan pada tahun 1985 oleh Bupati Malang.

Kelurahan Tlogomas dulunya merupakan bagian dari Kerajaan Kanjuruhan, yang mana daerahnya meliputi , Kelurahan Dinoyo, Kelurahan Merjosari dan Kelurahan Tlogomas. Maka dari itu di Kelurahan Tlogomas, Kelurahan Merjosari dan Kelurahan Dinoyo ada beberapa situs peninggalan Kerajaan Kanjuruhan, seperti di Kelurahan Tlogomas ada situs Watu Gong yang berada di wilayah RW.03 Kelurahan Tlogomas.

Berdasarkan Peraturan Pemerintah No. 15 Tahun 1987 tanggal 12 Juli 1987 tentang perubahan batas wilayah Kotamadya Daerah Tingkat II Malang, maka Pemerintah Kotamadya Daerah Tingkat II Malang yang semula terdiri dari 3 kecamatan :

1. Kecamatan Blimbing

2. Kecamatan Klojen

3. Kecamatan Kedungkandang

Pada bulan April 1988, dengan semakin berkembangnya jumlah penduduk di Kota 
Malang, maka Kecamatan Lowokwaru terpisah dari Kecamatan Blimbing dengan membawahi 12 kelurahan, meliputi : Kelurahan Tlogomas, Kelurahan Lowokwaru, Kelurahan Tasikmadu, Kelurahan Tunggulwulung, Kelurahan Tlogomas, Kelurahan Merjosari, Kelurahan Dinoyo, Kelurahan Sumbersari, Kelurahan Ketawanggede, Kelurahan Tulusrejo, Kelurahan Jatimulyo dan Kelurahan Mojolangu.

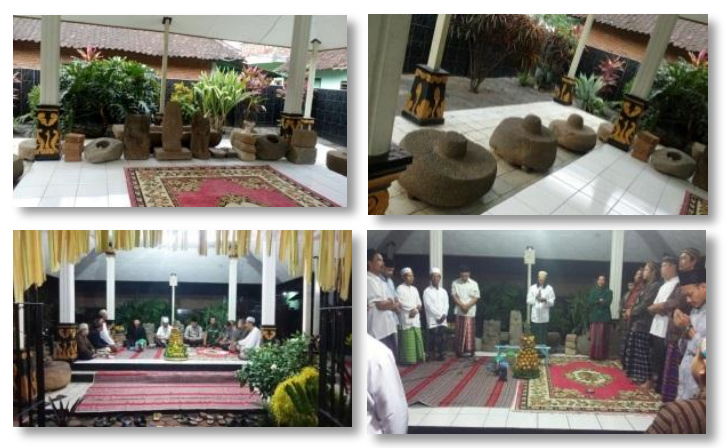

Gambar 2.1 Kondisi Peninggalan Watu Gong yang Berada Di Kelurahan Tlogomas Malang

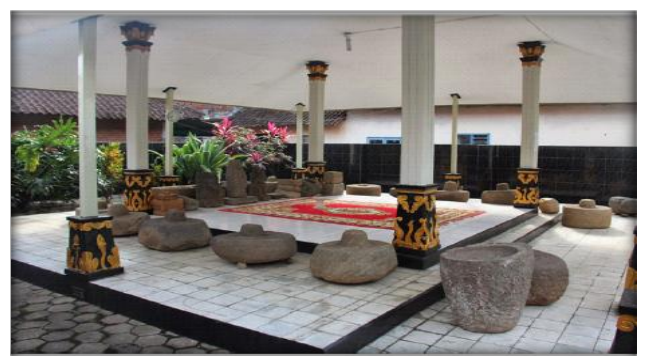

Gambar 2.2 Situs Watugong, Benda-Benda Tersebut Merupakan Salah Satu Peninggalan Kerajaan Kanjuruhan Pada Abad Ke 7 Masehi

\section{b) Perkembangan Kampung Watu Gong Hingga Saat ini}

Untuk perkembangan Kampung Watu Gong pada kondisi eksisiting cukup signifikan, hal ini dibuktikan dengan semakin banyakanya pengunjung baik dari dalam kota maupun dari luar kota yang berkunjung ke situs tersebut, walaupun pada kondisi saat ini masih minimnya petunjuk arah yang menuju lokasi situs tersebut. Dalam perkembangannya nantinya akan diberikan perunjuk atau rambu-rambu yang menunjang menunju tempat lokasi situs Di Kelurahan Tlogomas RW 03 Kota Malang. Selain itu adapun prestasi yang diraih oleh Kelurahan Tlogomas antara lain

1. Juara 2 Lomba Balita Sehat Tingkat Kota

2. Juara 2 Lomba Posyandu Tingkat Kota 3. Juara I Lomba Lansia Tingkat Propinsi

4. Juara III Lomba Kelurahan Berseri Tingkat Kota;

5. Juara Lomba BKM Tingkat Propinsi

6. Juara Harapan I Lomba Senam PKK Tingkat Kota;

7. Juara 2 Lomba Zero Waste Tingkat Kota

8. Juara Harapan I Lomba Cipta Menu Tingkat Kota.

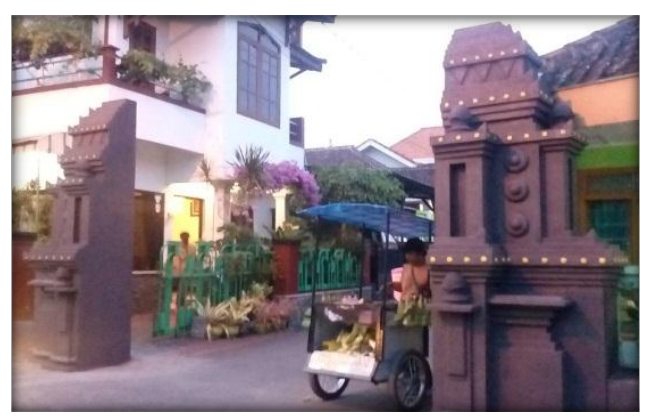

Gambar 2.3 Gerbang Pintu Masuk Menuju Ke arah Situs Watu Gong Yaitu Berada Di Jalan Kanjuruhan Gang IV RT 04/ RW 03 Tlogomas 


\section{Metode Kegiatan}

Adapun beberapa metode yang dipergunakan antara lain

\section{a) Prospek Umum Pengembangan}

\section{Kegiatan}

Kota Malang memiliki segudang aset dan potensi untuk bisa mewujudkan perancangan kota secara ideal, memberi nilai tambah fisik dan non-fisik. Secara umum Kegiatan Perancangan "Kampung Wisata Watu Gong" dalam rangka membangun sinergi antara Pemerintah Kota Malang, masyarakat, akademisi dan komunitas untuk berpartisipasi aktif dalam membangun Kota Malang melalui perkampungan yang potensial untuk menjadi destinasi wisata sejarah. dan secara khusus kegiatan ini memiliki manfaat sebagai berikut:

1) Melestarikan peninggalan seajarah yaitu situs Watugong

2) Mengembangkan bakat dan kreatifitas warga untuk mewujudkan RW. 03 Tlogomas menjadi sebuah "Kampung Wisata Watu Gong" dan menjadi salah satu destinasi wisata baru di kota Malang

3) Menggerakan roda perekonomian masyarakat akibat banyak orang yang berkunjung untuk membeli souvenir dan oleh-oleh.

b) Potensi, Masalah, Kekuatan Dan Kelemahan Kampung Watu Gong Kelurahan Tlogomas Kota Malang

- Analisis SWOT (Strength Weakness Opportunity dan Threat )
Analisis SWOT adalah metode analisis yang digunakan dalam mengidentifikasi potensi dan masalah serta digunakan juga sebagai dasar kebijakan dari strategi pengembangan. Analisis SWOT merupakan salah satu teknik analisis yang digunakan dalam menginterpretasikan suatu wilayah, khususnya pada kondisi yang sangat kompleks dimana faktor eksternal dan faktor internal memegang peranan yang sama pentingnya. Analisis SWOT yang digunakan ini bertujuan untuk menentukan arahan-arahan dalam mengembangkan kampung wisata Watu Gong ke depannya.

Analisis SWOT adalah analisis untuk mengetahui faktor-faktor yang mempengaruhi kondisi wilayah, yaitu untuk melihat Strength (kekuatan), Weakness (kelemahan), Opportunity (peluang) dan Threat (ancaman), dan menginventarisasi faktor-faktor tersebut dalam strategi perencanaan sebagai dasar untuk menentukan langkah-langkah perbaikan yang diperlukan dalam pengembangan selanjutnya. Faktor-faktor yang mempengaruhi pengembangan tersebut adalah:

a) Potensi (Strength)

Kekuatan yang dapat dikembangkan agar lebih tangguh, sehingga dapat bertahan di pasaran, yang berasal dari dalam wilayah itu sendiri

b) Masalah (Weakness)

Segala faktor yang merupakan masalah atau kendala yang datang 
dari dalam wilayah atau obyek itu sendiri

c) Peluang (Opportunities)

Kesempatan yang berasal dari luar wilayah. Kesempatan tersebut diberikan sebagai akibat dari pemerintah, peraturan atau kondisi ekonomi secara global.

d) Ancaman (Threat)

Merupakan hal yang dapat mendatangkan kerugian yang berasal dari luar wilayah atau obyek.

\section{c) Analisis Fisik Lingkungan}

Beberapa potensi fisik dan non fisik yang mendukung terealisasinya pengembangan kampung wisata seperti hal-hal berikut:

1) Potensi Akses Jalan yang mudah

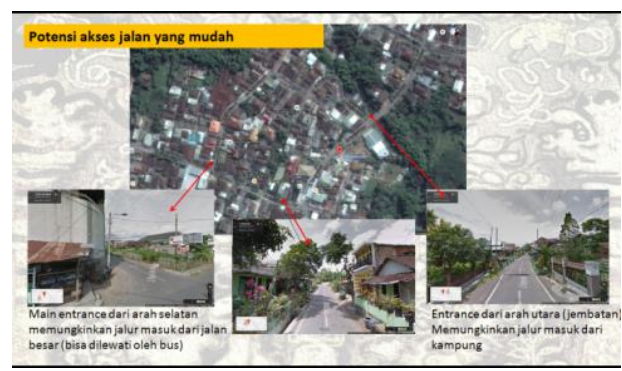

Gambar 3.1 Aksesibilitas

2) Terdapat Sumber air dan daerah aliran sungai

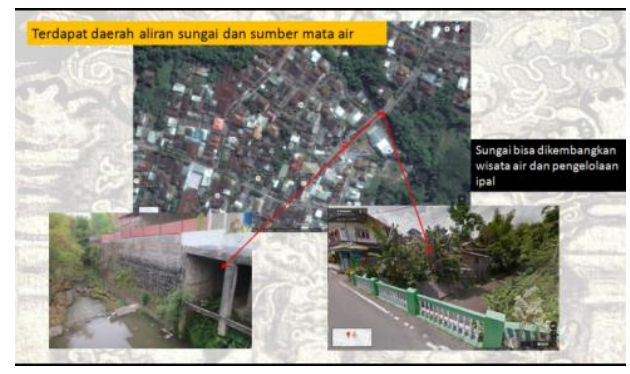

Gambar 3.2 Daerah aliran sungai

3) Terdapat Situs Peninggalan Kerajaan Kanjuruhan

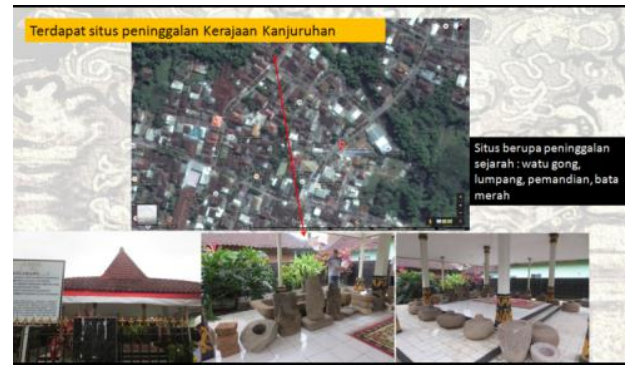

Gambar 3.3 Pendopo

4) Produksi Kerajinan masyarakat lokal seperti kompor dan pengolahan limbah plastik

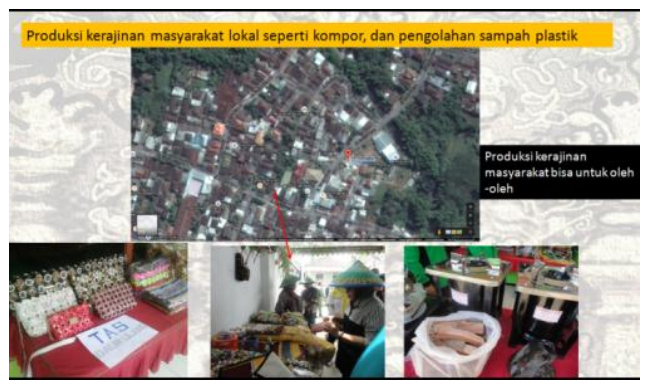

Gambar 3.4

Kerajinan masyarakat lokal

5) Tersedianya gapura yang memiliki unsur sejarah

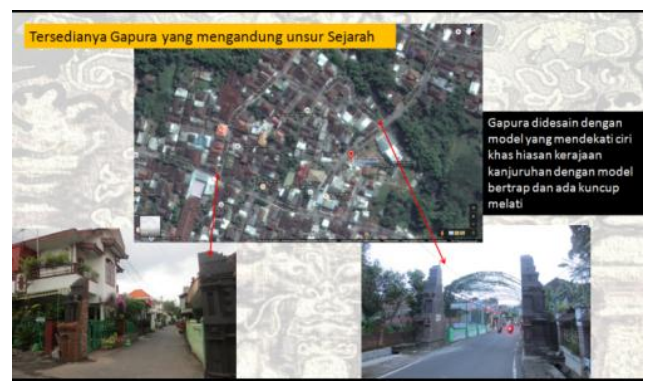

Gambar 3.5 Gapura Gerbang Utara

6) Terselenggaranya beberapa eveneven kesenian tradisional

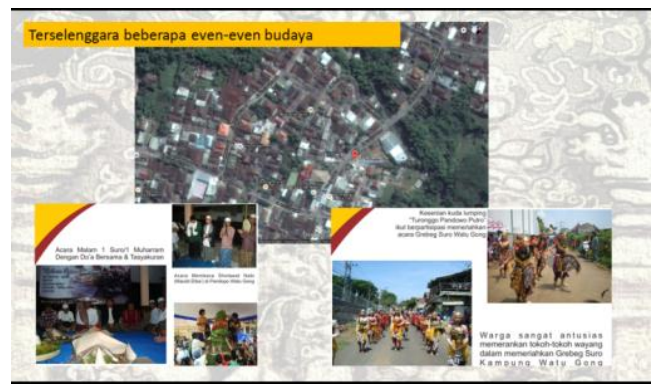

Gambar 3.6 even-even budaya di RW 03 
d) Proyeksi-Proyeksi Masa Depan

Dalam mewujudkan dan mengembangkan potensi yang berada Di Kelurahan Tlogomas utamanya di RW 03, maka perlu memaksimalkan potensipotensi yang dimiliki, dengan menggunakan stable growth strategy, yaitu

1) Mewujudkan dan memproyeksikan kreasi perancangan kawasan utamanya Kelurahan Tlogomas dengan menitik beratkan tema budaya melalui mekanisme perencanaan partisipatif dengan melibatkan seluruh elemen masyarakat sebagai dasar untuk pengambilan keputusan bersama

2) Menata dan mengembangkan kawasan menjadi sebuah destinasi wisata baru Di Kota Malang

3) Memproyeksikan Kampung Watu Gong menjadi salah satu tujuan wisata yang berada Di Kota Malang dengan menampilkan potensi dan atraksi

4) Menjadikan dan meproyeksikan Kampung wisata Watu Gong menjadi kampong yang mengusung unsur-unsur edukatif, ekologis, budaya, estetika, dan bernilai ekonomi yang menimbulkan multiplier effect bagi masyarakat sekitarnya

\section{e) Analisis Penggunaan Ruang Dan Pengembangan Ruang}

Dalam perancangan kampung Sejarah Watu Gong ini kami mengusung 5 unsur desain yaitu:

1. Edukatif

2. Ekologis

3. Budaya

4. Estetika

5. Ekonomi

\section{f) Telaah Kelembagaan}

Analisis ini bertujuan untuk mengetahui dan mengidentifikasi pelakupelaku yang berbeda beserta kepentingannya terhadap suatu pengembangan dan perencanaan kampung wisata Watu Gong, yang terkait dengan membuat format "Matriks Analisis Partisipatif".

\section{g) Telaah Readiness Criteria (Status Kesiapan Fisik Dan Nonfisik)}

a) Pada zona inti (kawasan pendopo agung)

b) Gapura Utama dan gapura setiap kampung

c) Area Parkir

d) Area pendukung

\section{KARYA UTAMA}

Adapun hasil dari jurnal Perencanaan dan Perancangan Kampung Wisata Watu Gong Kelurahan Tlogomas RW 03 Kecamatan Lowokwaru Kota Malang berupa arahan dan strategi.

Berdasarkan hasil inventarisasi pada lingkungan RW 03 Kelurahan Tlogomas dan hasil respondensi masyarakat lokal, maka 
didapatkan faktor-faktor yang mempengaruhi dalam strategi pengembangan kampung wisata Watu Gong. Dalam proses analisa tapak didapatkan data terkait kekuatan, kelemahan, peluang dan ancaman sebagai berikut:

\section{Tabel 4.1 Matriks Analisis Internal} (Strength dan Weakness)

\section{ANALISIS INTERNAL}

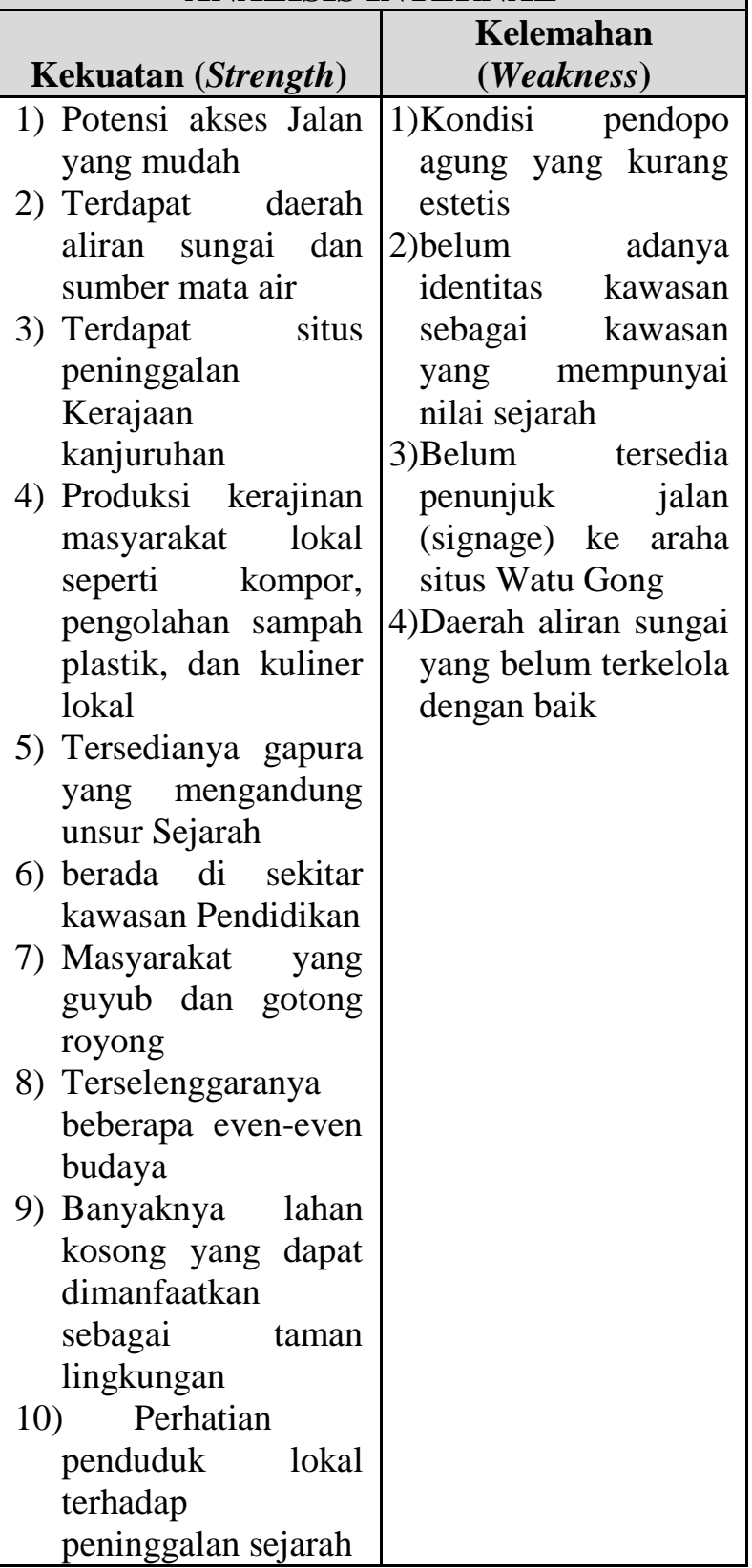

Sumber: Hasil Survey primer 2016
Matriks Analisis Eksternal (Opportunities dan Threats) ANALISIS EKSTERNAL

\begin{tabular}{|c|c|}
\hline ANeluang & $\begin{array}{c}\text { Ancaman } \\
\text { (Threats) }\end{array}$ \\
\hline (Opportunities)
\end{tabular}

1) Peran Pemerintah 1) Alih fungsi yang sinergis lahan dengan 2 2) Arus pengembangan modernisasi kampung wisata 3) Sifat apatis sejarah (Kampung terhadap nilaiTematik)

2) Banyaknya pengunjung dari luar kota ke area situs

3) Dekat dengan fasilitas pendidikan

4) Dapat menjadi laboratorium atau media penelitian bagi institusi pendidikan

5) Menjadi tempat pelatihan-pelatihan tentang seni dan kebudayaan

6) Pengembangan wisata kuliner tradisional nilai sejarah dan kebudayaan

4) Menurunnya kegiatankegiatan yang bersifat kebudayaan

5) Padatnya area pemukiman

6) Rendahnya kepedulian pemerintah terhadap kawasankawasan bersejarah

$$
\text { Dalam mewujudkan dan }
$$
mengembangkan potensi yang berada Di Kelurahan Tlogomas utamanya di RW 03, maka perlu memaksimalkan potensipotensi yang dimiliki, dengan menggunakan stable growth strategy, yaitu :

1) Mewujudkan dan memproyeksikan kreasi perancangan kawasan utamanya Kelurahan Tlogomas dengan menitik beratkan tema budaya melalui mekanisme perencanaan partisipatif dengan melibatkan seluruh elemen 
masyarakat sebagai dasar untuk pengambilan keputusan bersama

2) Menata dan mengembangkan kawasan menjadi sebuah destinasi wisata baru Di Kota Malang

3) Memproyeksikan Kampung Watu Gong menjadi salah satu tujuan wisata yang berada Di Kota Malang dengan menampilkan potensi dan atraksi

4) Menjadikan dan meproyeksikan Kampung wisata Watu Gong menjadi kampong yang mengusung unsurunsur edukatif, ekologis, budaya, estetika, dan bernilai ekonomi yang menimbulkan multiplier effect bagi masyarakat sekitarnya

Dalam perancangan kampung Sejarah Watu Gong ini kami mengusung 5 unsur desain yaitu:

1. Edukatif

2. Ekologis

3. Budaya

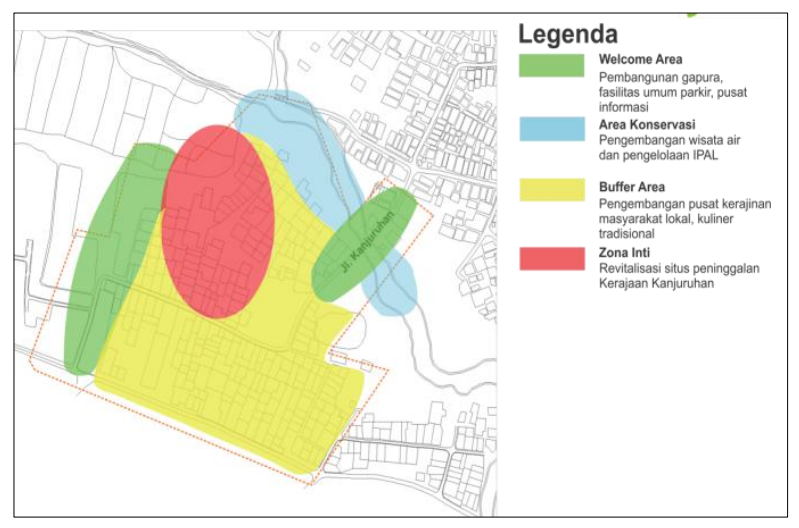

4. Estetika

Gambar 4.1 Pembagian Zona Kegiatan
- Welcome Area : (Edukatif, Sejarah, Estetika)

1. Pembangunan Gapura dengan Muatan Sejarah

2. Pembangunan Fasilitas Umum (Parkir, Pusat Informasi dll)

3. Relief selamat datang yang bermuatan Sejarah dan Edukasi

4. Sculpture tentang Watu Gong

5. Penambahan vegetasi lokal untuk memberi kesan alami dan sejuk

- Zona Inti (Sejarah, Estetika, ekologi dan Edukasi)

1. Pemugaran pendopo Situs

2. Redesain Kawasan Kampung dengan ornamen-ornamen Sejarah

3. Pemugaran setiap pagar rumah dengan memberikan pucuk pilar berbentuk kuncup melati

4. Penambahan vegetasi-vegetasi lokal untuk menambah kesan alami

5. Perancangan relief-relief pada tembok yang bermuatan edukasi dan sejarah

- Zona Konservasi (Ekologi, Edukasi, rekreasi)

1. Revitalisasi Kawasan Daerah aliran sungai

2. Penghijauan kawasan sungai

3. Pengelolaan IPAL yang terletak di dekat sungai

4. Penyediaan Trap-trap untuk area memancing

5. Pengembangan sebagai kawasan penelitian Daerah Aliran sungai

6. Perancangan Flying Fox (Additional) 
- Zona Buffer (Edukasi, Ekonomi, Kuliner dan Sejarah)

1. Pengembangan Kerajinan masyarakat lokal

2. Kawasan kuliner tradisional

3. Tempat pemasaran kerajinan dan produk masyarakat lokal

4. Penambahan vegetasi lokal untuk menambah kesan sejuk dan alami

5. Membuat sculpture tentang Watu gong dan Kerajaan Kanjuruhan

6. Meredesain setiap pagar rumah dengan muatan sejarah (Kanjuruhan)

7. Membuat relief-relief yang bermuatan sejarah (Kanjuruhan)

\section{UlaSAN KARYA}

Pengguna tapak bisa dewasa/anakanak dengan jam berkunjung 08.00-17.00, dengan kendaraan, mobil, bus, dan motor datang dari pintu gerbang selatan. Sepanjang entrance ditampilkan relief Kerajaan Kanjuruhan pada dinding menuju area parkir di bawah tower. Pengunjung berjalan kaki menuju kawasan situs, dengan dihadirkan pedagang kuliner, souvenir sepanjang jalan yang dihiasi oleh sewu gong sebagai karakter watu gong. Tiap jalan masuk terdapat gapura dengan hiasan Kerajaan Kanjuruhan. Kawasan situs dijadikan sebagai sarana pembelajaran sejarah dan budaya. Pengunjung dapat pula menikmati suasana daerah aliran sungai yang asri yang dilengkapi dengan wisata air seperti area pemancingan.

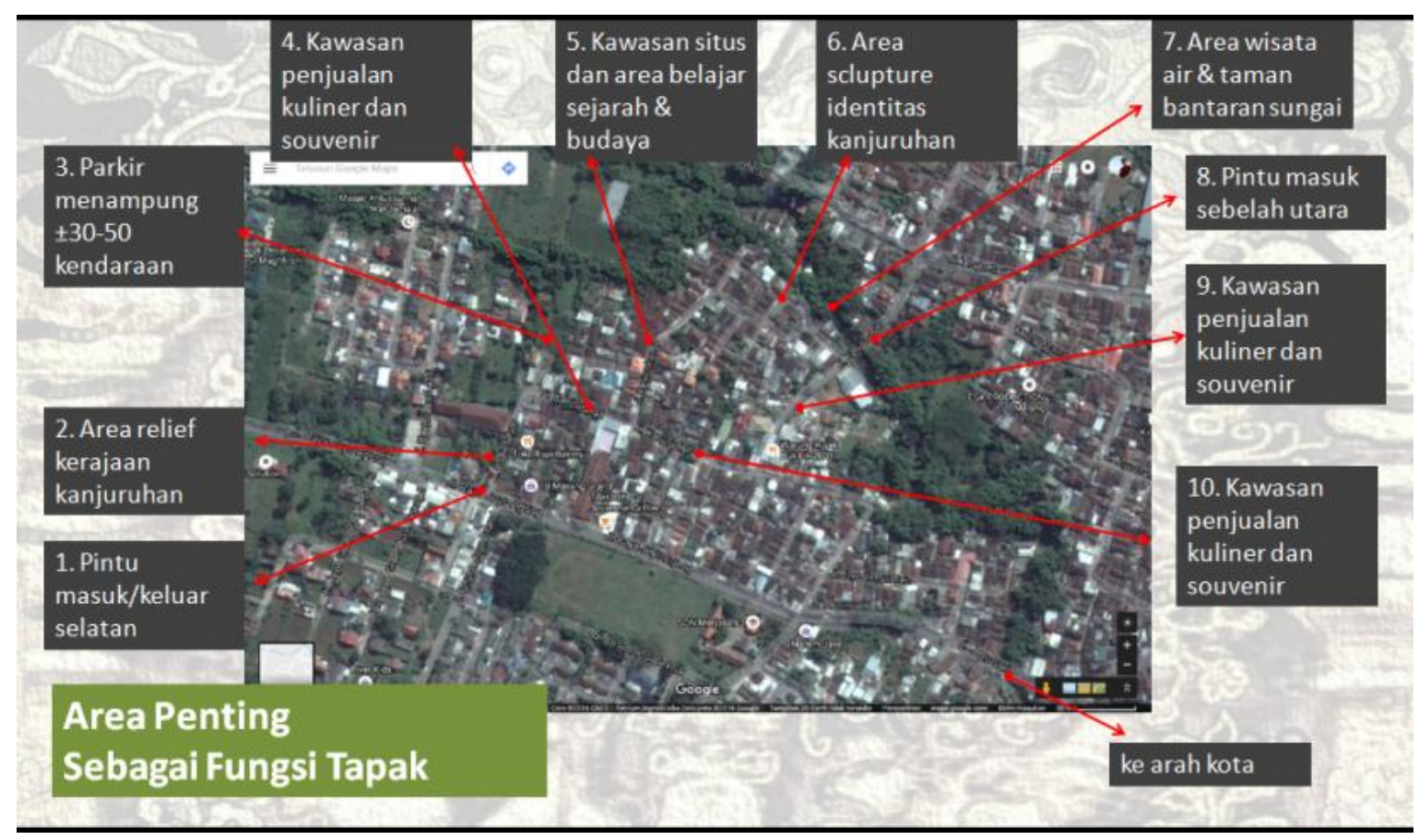

Gambar 5.1 Area Penting dan Fungsi Tapak 


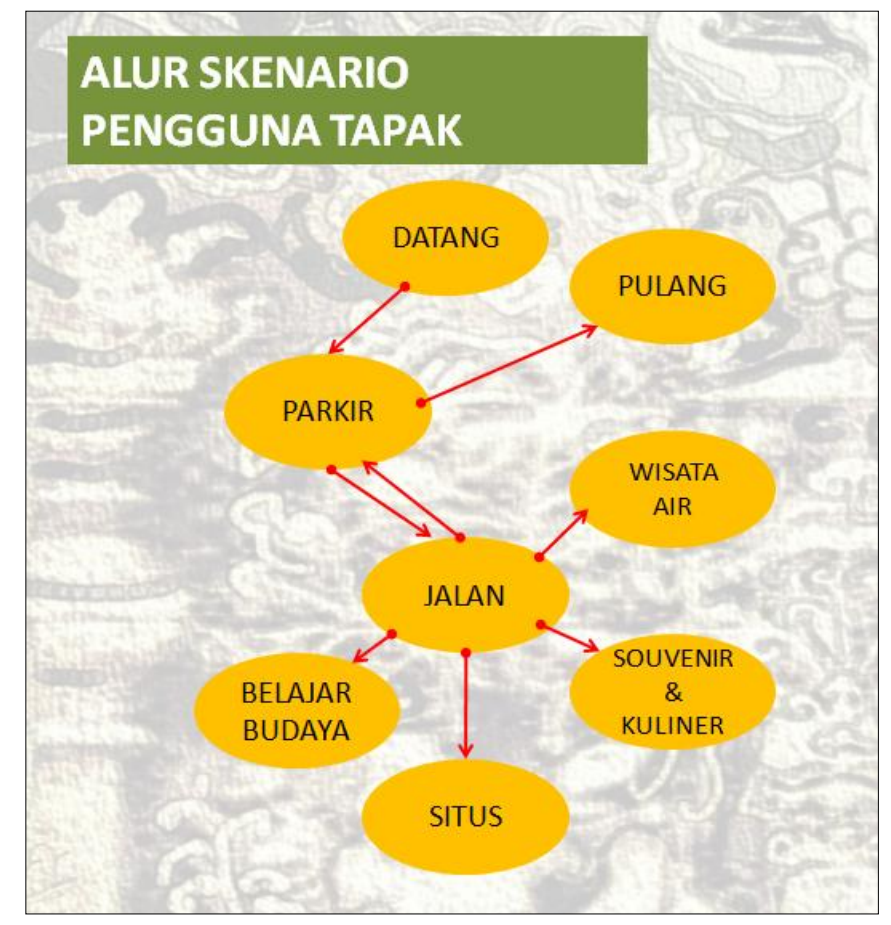

Gambar 5.2 Alur Skenario Pengguna Tapak

\section{KESIMPULAN}

Kota Malang memiliki segudang aset dan potensi untuk bisa mewujudkan perancangan kota secara ideal, memberi nilai tambah fisik dan non-fisik. Salah satu event Kota Malang melalui Badan Perencanaan Pembangunan Daerah yaitu menyelenggarakan Festival Rancang Malang. Kegiatan ini merupakan sebuah kegiatan kompetisi perancangan yang dilakukan secara partisipatif oleh masyarakat, dibantu tim pendamping yaitu dari UNITRI (Universitas Tribhuwana Tunggadewi).

Salah satunya Kelurahan yang berada Di Kota Malang yaitru Kelurahan Tlogomas. Kelurahan ini yang memiliki peninggalan sejarah pada jaman Kerajaan Kanjuruhan. Beberapa situs dan peninggalan kerajaan pada masa itu yang tersebar berada Di Kelurahan Tlogomas Di RW 03 Kota Malang. Beberapa potensi fisik dan non-fisik di Kampung Watu Gong Tlogomas terutama Di RW 03 antara lain potensi jalan yang mudah, sumber air dan daerah aliran sungai, terdapat Situs Peninggalan Kerajaan Kanjuruhan, produksi Kerajinan masyarakat lokal seperti kompor dan pengolahan limbah plastik, tersedianya gapura yang memiliki unsur sejarah dan terselenggaranya beberapa even-even kesenian tradisional. Gambaran objek atau ide rancangan dari perencanaan yang berada Di Kelurahan Tlogomas RW 03 Kecamatan Lowokwaru Kota Malang terdiri dari 6 (enam) bagian meliputi : 
1) Pintu gerbang utama

2) Sepanjang jalan Kanjuruhan (utara)

3) Sepanjang jalan Kanjuruhan (Timurbarat

4) Pintu gerbang selatan

5) Gang IV(kawasan menuju situs)

6) Pendopo Agung

Strategi yang dilakukan dalam mengenbangkan kampugnwisata Watu Gong adalah pengaplikasian 5 unsur (unsur edukatif, ekologis, budaya, estetika dan unsur ekonomi) ke dalam masing-masing zonasi perencanaan ruang (Zona inti, zona pengembangan/buffer area dan zona konservasi).

\section{DAMPaK dan MANFAAT Kegiatan}

Adapun dampak atau pengaruh yang dihasilkan dari jurnal Perencanaan dan Perancangan Kampung Wisata Watu Gong Kelurahan Tlogomas RW 03 Kecamatan Lowokwaru Kota Malang adalah :

1) Memberikan arahan dan strategi yang tepat dalam pengembangan kampung wisata Watu Gong Kelurahan Tlogomas RW 03 Kecamatan Lowokwaru Kota Malang

2) Memberikan dampak multiplier efect bagi para pedagang yang berjualan disekitar situs Watu Gong

3) Sebagai dasar/pedoman perencanaan kawasan kampung wisata bagi pemerintahan Kota Malang

4) Memberikan gambaran perencanaan yang sistematis dan terintegrasi dengan berbagai aspek yang terlibat
5) Memberikan penataan kawasan yang lebih efektif dan efisien

\section{DAftar Pustaka}

Gallion and Eishner, (1992), Pengantar Perancangan Kota. Jakarta: Erlangga.

Zahnd, Markus, (2006), Perancangan Kota Secara Terpadu: teori perancangan kota dan penerapannya. Yogyakarta: Kanisius.

Budiharjo, 2004, Permukiman, Penerbit Ghalia Indonesia

Dahuri,Rokhmin, 2004, Pembangunan Wilayah : Perspektif Ekonomi, Sosial dan Lingkungan, LP3ES, Jakarta.

Hendra, L, 2001, Sistem Informasi Geografis, Penerbit Ghalia Indonesia

Undang-Undang Nomer 24 Tahun 1992 Tentang Penataan Ruang

Undang-Undang Nomor 26 Tahun 2007 Tentang Penataan Ruang.

Undang-Undang Nomor 1 Tahun 2011 TentangPerumahan dan Kawasan Permukiman.

\section{ix. Penghargaan}

Adapun ucapan terima kasih kepada :

1) Bapak Lurah Tlogomas, Bapak. Aryadi Wardoyo. S.STP., MSi

2) Seluruh warga Kelurahan Tlogomas RW 03 Kecamatan Lowokwaru Kota Malang

3) Rekan-rekan team yang telah membantu dalam penyusunan jurnal Perencanaan dan Perancangan 
Jurnal Aplikasi Sains dan Teknologi - JAST, Volume 1, Nomor 1, Januari-Juni 2017, e-ISSN 2548-7981

Kampung Wisata Watu Gong

Kelurahan Tlogomas RW 03

Kecamatan Lowokwaru Kota Malang

4) Team koordinasi perancang lomba

Kampung Tematik Kelurahan

Tlogomas RW 03 Kecamatan

Lowokwaru Kota Malang 